changing soil landscape over time.

The principal results are these. That there was an initial period of minor soil disturbance in the basin between about 1900 and $1250 \mathrm{BC}$ (calibrated), coincident with the appearance of maize pollen. That a second, more intense episode of erosion occurred from about $600 \mathrm{BC}$ to $\mathrm{AD} 650$, linked to late Preclassic/early Classic occupation and concentrated in the northern part of the basin. And that a third, particularly destructive interval of soil erosion took place after AD 1200; this was initially centred on the Postclassic Tarascan (Purépecha) centre of Tzintzuntzan, and was followed by a slight decline in topsoil removal and a modest increase of mineral soil erosion after about 1500 , during the Spanish and Mexican periods. Rates of soil-derived sedimentation averaged 10,300 tons a year before about AD 650, 29,000 tons a year after about AD 1200, and 4,500 tons a year between these dates.

These figures show vividly that prehispanic indigenous land-use was not conservationist in practice. The curves suggest that an immediate response to reoccupation of the basin was an initial flush of topsoil, followed by a rapid, steady increase in mobilization of mineral sediment. Preclassic/Classic doubling of sedimentation rates implies that disturbance of the basin was then relatively modest, but Postclassic settlement provoked a sixfold increase and probably was environmentally destructive. The full scope of disturbance is barely hinted at in the coarse-grained pollen record from the basin ${ }^{2}$, which does not support the impli- cit notion of a deforested catchment. 'Shifting' hillslope farming, with fairly substantial fallow periods, today favours an irregular cover of secondary woodland in those humid parts of Mexico with indigenous-style farming, more consonant with the persistent oak and other deciduous, arboreal pollen represented in the palynological record.

A small Spanish town was founded at Pátzcuaro in 1537 , but Spanish agricultural settlement was concentrated beyond the catchment, in Morelia; local Spanish land-use was probably limited to initial, mobile cattle-raising, soon followed by winter pasturing of sheep from drier parts of the plateau. Traditional, indigenous land-use persisted around the lake, despite a steadily declining Tarascan population; but the new bishop introOBITUARY

\title{
Robert W. Holley (1922-1993)
}

IN a remarkable decade from the mid1950s to the mid-1960s, a series of discoveries established the foundation of our understanding of how genetic information is expressed in living systems. Robert W. Holley, one of the major figures of this period, died of lung cancer on 11 February at Los Gatos, California, north of the Salk Institute where he had been a resident Fellow for the past 25 years. Holley's principal contribution was in isolating and determining the nucleotide sequence of the first transfer RNA, so providing enormous insight into one of the fundamental events in protein synthesis.

His work started in 1956, on a sabbatical that he took at the California Institute of Technology from Cornell University, when he carried out experiments designed to detect the acceptor of activated amino acids. It was in the mid-1950s that Francis Crick proposed the 'adaptor hypothesis', that a small nucleic acid molecule might act as an adaptor for aligning amino acids along a ribonucleic acid chain during protein synthesis. During this period Mahlon Hoagland, Paul Zamecnik and others showed that radioactive amino acids became bound to a low-molecular-weight RNA, later called transfer RNA. It quickly became apparent that there were at least 20 classes of transfer RNA molecule, each capable of accepting an individual amino acid. To understand the process fully, it became necessary to isolate an individual species and then to determine its nucleotide sequence.

Holley's background made him wellsuited to tackle this task. He had received a PhD in organic chemistry at Cornell in 1947 , following his undergraduate training at the University of Illinois. He taught organic chemistry and also worked in a laboratory of the US Department of Agriculture at Cornell. He selected the method of counter-current distribution, and developed it to the point where it that Holley's effort represented the beginning of this process, albeit in the much more difficult world of RNA sequencing.

He was very interested in the secondary and tertiary structure of the alanine transfer RNA. Out of his work came the well-known clover-leaf secondary structure with the anticodon bases in one loop. Virtually all transfer RNAs sequenced subsequently have this clover-leaf arrangement; its full significance was realized in 1973 , in $X$-ray diffraction studies that revealed the backbone folding of yeast phenylalanine transfer RNA, which produces an L-shaped structure with the anti-codon at one end and the amino-acid acceptor at the other end, more than 70 ångströms away.

could separate individual transfer RNA molecules which were assayed by their ability to accept a specific amino acid. Starting in 1958, it took three years of hard labour to isolate a purified species of the alanine acceptor transfer RNA from yeast. He began with $140 \mathrm{~kg}$ of commercial yeast and extracted $200 \mathrm{gm}$ of transfer RNA which yielded $1 \mathrm{gm}$ of the purified alanine species.

During the next four years, Holley developed methods that made it possible to determine the nucleotide sequence of this purified species. He introduced many innovations in that work, and the sequence was determined by using two sequence-specific ribonucleases which broke the molecule into smaller fragments that could be sequenced. Partial digests allowed him to obtain larger fragments which ultimately led to the sequence of the entire molecule. In the age of the Human Genome Project, in which we talk about kilobases of nucleotide sequence, it is important to realize
Holley's elucidation of the nucleotide sequence of the transfer RNA molecule occurred in the same period during which the genetic code was being deciphered, and he shared the 1968 Nobel prize with Marshall Nirenberg and $H$. Gobind Khorana, who played major roles in deciphering the code. He moved to the Salk Institute in 1968 , where he worked productively on factors that stimulate growth in mammalian cells.

Robert Holley was a modest man with a quiet and warm personality, an avid interest in science and a keen appreciation of the thrill of scientific discovery. As a hobby, he worked as a sculptor, and those who have seen his elegant bronze statues realize that he could have had another calling, had he elected not to go into science.

Alexander Rich

Alexander Rich is in the Department of Biology, Massachusetts Institute of Technology, 77 Massachusetts Avenue, Cambridge, Massachusetts 02139, USA. 